\title{
Perbandingan Pola Sinyal Penyakit Myocardial Infarction dengan Jantung Normal Menggunakan Metode Wavelet Symlet
}

\author{
Markus Aminius Gielbert ${ }^{1}$, Nabila Husna Shabrina ${ }^{2}$, Andre Wijaya ${ }^{3}$, Jeremy Pratama Wijaya ${ }^{4}$ \\ 1,3,4 Teknik Fisika, Fakultas Teknologi dan Informatika, Universitas Multimedia Nusantara, Tangerang, \\ Indonesia \\ markus.aminus@student.umn.ac.id \\ andre.wijaya@student.umn.ac.id \\ jeremy.pratama@student.umn.ac.id \\ ${ }^{2}$ Teknik Komputer, Fakultas Teknologi dan Informatika, Universitas Multimedia Nusantara, Tangerang, \\ Indonesia \\ nabila.husna@umn.ac.id
}

Diterima 26 Mei 2020

Disetujui 16 Juni 2020

\begin{abstract}
On the signal of healthy human cardiography and people with myocardial infarction contain a lot of noise. For this reason, it is necessary to process the appropriate signal so that the information contained by the signal can be detected easily. Stages of research include data search, pre-processing, signal processing with the denoise Wavelet Symlet method, and qualitative comparison of cardiographic signal patterns resulting from normal human signal processing with myocardial infarction. To eliminate noise on ECG signals, the denoise method using Wavelet Symlet is proven to be better than the Finite Impulse Response (FIR) Hamming Windows filter. MATLAB is one of the software options that can be used in processing cardiographic signals with denoise Wavelet Symlet method, proven to have a fairly high reliability based on qualitative analysis. This trial also proved that the pattern of human cardiographic signals with myocardial infarction disorders was quite random and and differed from one patient to another. However, slower heart rate patterns, greater amplitude, and abnormalities in the $P$, $T$ signal and stretching $Q-S$ distances can be a reference for diagnosing someone with myocardial infarction.
\end{abstract}

Index Terms-Elektrokardiografi (EKG), MATLAB, Myocardial Infarction, Pola Sinyal Kardiografi, Wavelet Symlet

\section{PENDAhUluan}

Myocardial Infarction atau lebih lazim dikenal dengan serangan jantung merupakan salah satu penyebab kematian terbesar di Indonesia. Serangan jantung merupakan suatu kondisi ketika aliran darah ke jantung tersumbat. Umumnya, ini disebabkan oleh penyakit jantung koroner akibat otot jantung kekurangan darah karena adanya penyempitan pembuluh darah koroner. Berdasarkan data Badan Kesehatan Dunia (WHO) pada 2016, total kematian di Indonesia mencapai 1.863 .000 jiwa [1]. Sebanyak 73 persen di antaranya disebabkan oleh penyakit tidak menular. Adapun jantung koroner menjadi penyebab kematian nomor 1 sebanyak 35 persen dari seluruh penyakit tidak menular tersebut [1].

Untuk mengetahui kondisi apakah seseorang mengidap penyakit Myocardial Infartion biasanya digunakan alat elektrokardiografi (EKG). Di rumah sakit, petugas medis dituntut untuk memiliki kemampuan yang cukup dalam mengidentifikasi penyakit ataupun anomali yang dialami jantung pasien melalui rekaman EKG, khususnya untuk mengenal potensi penyakit serangan jantung ini. Namun pada kenyataannya, banyak petugas medis yang bahkan tidak mengerti cara membaca sinyal kardiografi hasil rekaman EKG dan beralasan bahwa tanggung jawab dalam mengindentifikasi masalah jantung dimiliki oleh dokter jantung dan bukan petugas medis lainnya. Hal ini menyebabkan keterlambatan penyaluran informasi kepada pasien ataupun keluarga pasien sehingga penanganan dalam kasus-kasus yang memerlukan tindakan cepat menjadi terhambat [2].

Sinyal kardiografi merupakan gambaran sinyal yang dihasilkan oleh jantung dengan meletakkan dua belas sadapan ke beberapa bagian permukaan tubuh pasien menggunakan perangkat elektrokardiografi (EKG). Sinyal kardiografi ini membantu para dokter untuk mendiagnosis kelainan atau anomali jantung pada pasien, termasuk kondisi saat seseorang mengalami Myocardial Infarction. EKG adalah suatu gambaran sinyal yang dihasilkan oleh jantung dan merupakan rekaman grafik potensial-potensial listrik yang ditimbulkan oleh jaringan jantung. Grafik ini kemudian akan difiltrasi dan diproses sehingga memudahkan pembacaan. Pasien pengidap Myocardial Infarction pada dasarnya memiliki sinyal kardiografi dengan pola yang tidak beraturan, cukup berbeda dari pola kardiografi manusia sehat. Melalui 
grafik yang telah diolah seharusnya petugas medis dapat membandingkan dengan mudah hasil kondisi jantung pasien dengan grafik jantung manusia sehat yang sudah tersimpan dalam database rumah sakit, sehingga adanya penyakit Myocardial Infarction pada jantung pasien langsung dapat terdeteksi dan diberikan penanganan khusus sesuai dengan dengan keperluannya. Penelitian ini secara khusus hendak memperjelas apa saja perbedaan pola sinyal penyakit Myocardial Infarction dengan jantung normal secara kuantitatif, sehingga memudahkan petugas medis dalam pendeteksian gejala serangan jantung di rumah sakit.

Penelitian serupa pernah dilakukan oleh Evrita Lusiana Utari dan Agus Qomaruddin Munir dari Fakultas Sains \& Teknologi, Universitas Respati Yogyakarta dengan judul "Pengenalan Pola Sinyal Kardiografi dengan Menggunakan Alihragam Gelombang Singkat" [2]. Modifikasi yang peneliti lakukan pada penelitian ini adalah penyederhanaan metode kuantitatif menjadi kualitatif disertai dengan pengalihan tujuan utama menjadi perbandingan metode FIR filter Hamming Windows dengan denoise Wavelet Symlet, pengujian reliabilitas MATLAB terhadap pengolahan sinyal EKG, dan menemukan perbedaan pola sinyal kardiografi pengidap penyakit myocardial infarction dengan manusia sehat.

\section{DASAR TEORI}

\section{A. Myocardial Infarction}

Myocardial Infarction atau serangan jantung adalah suatu kondisi ketika kerusakan dialami oleh bagian otot jantung (myocardium) akibat pasokan darah yang berkurang secara signifikan dalam waktu yang singkat ke bagian otot jantung [3]. Berkurangnya pasokan darah ke jantung secara tiba-tiba dapat terjadi ketika salah satu nadi koroner terblokir selama beberapa saat, entah akibat spasme - mengencangnya nadi koroner - atau akibat penggumpalan darah thrombus. Bagian otot jantung yang biasanya dipasok oleh nadi yang terblokir berhenti berfungsi dengan baik segera setelah splasme reda dengan sendirinya, gejala-gejala hilang secara menyeluruh dan otot jantung berfungsi secara betul-betul normal lagi. Ini sering disebut crescendo angina atau coronary insufficiency. Sebaliknya, apabila pasokan darah ke jantung terhenti sama sekali, sel-sel yang bersangkutan mengalami perubahan yang permanen hanya dalam beberapa jam saja dan bagian otot jantung termaksud mengalami penurunan mutu atau rusak secara permanen. Otot yang mati ini disebut infark.

Singkatkan myocardial infarction merupakan penyakit yang terjadi akibat rusaknya beberapa sel jantung akibat tidak adanya aliran darah yang mencukupi menuju sel tersebut.

\section{B. Elektokardiografi (EKG)}

Elektrokardiografi atau EKG adalah tes yang dilakukan dengan cara merekam aktivitas listrik jantung selama periode waktu tertentu untuk memeriksa sebaik apa fungsi jantung pasien [4]. Proses perekaman EKG menggunakan 12 sadapan yang dipasang pada dada, lengan kanan, lengan kiri dan tungkai kaki sebelah kiri pasien. Elektokardiografi (EKG).

Jantung bekerja karena dipicu oleh hantaran sinyal listrik alami. Sinyal-sinyal inilah yang menyebabkan otot jantung berkontraksi untuk menciptakan detak jantung. Setiap kali jantung berdetak, gelombang (impuls) listrik akan mengalir dalam jantung. Gelombang ini menyebabkan otot-otot jantung meremas, kemudian memompa darah keluar dari jantung. Ketika terjadi suatu kelainan pada jantung, hantaran sinyal listrik ini akan ikut terganggu sehingga irama detak jantung juga dapat bermasalah dan menghasilkan pola sinyal yang berbeda dari pola sinyal jantung normal.

\section{Keteraturan Detak Jantung Normal}

Keteraturan detak jantung diatur oleh sistem listrik jantung [5]. Irama detak jantung normal menandakan bahwa kinerja listrik jantung berfungsi dengan baik. Detak jantung normal terdengar seirama, sama setiap ketukannya, monoton atau seragam, tidak ada suara atau detak jantung tambahan. Sedangkan pada detak jantung yang abnormal, iramanya bisa terdengar tidak beraturan, dan kadang terdapat suara detak jantung tambahan atau bising di luar suara detak jantung utama.

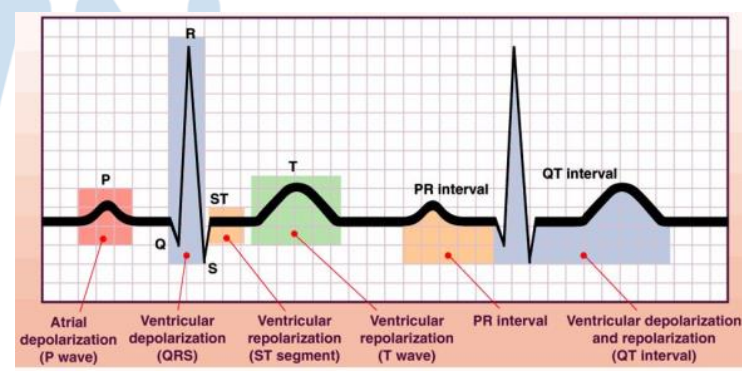

Gambar 1. Kurva standar EKG [6] 


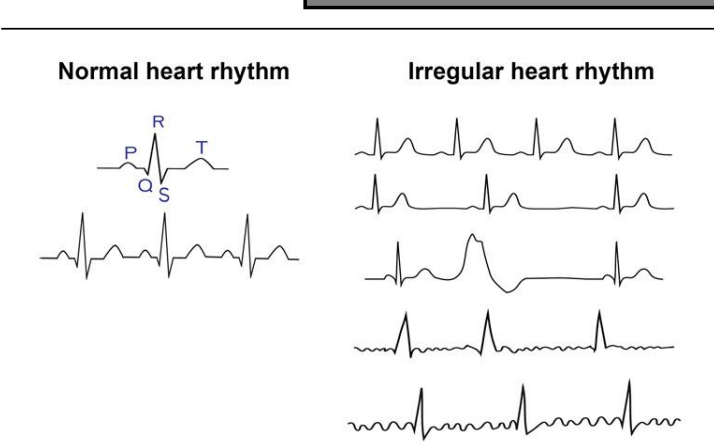

Gambar 2. Irama detak jantung yang normal (kiri) dan irama detak jantung yang abnormal (kanan) [7]

Yang membedakannya secara objektif selain dari iramanya (suara) detak jantung juga dari pergerakan grafik EKG. Pada Gambar 1 di atas, gelombang P, gelombang QRS, gelombang $\mathrm{T}$ beserta interval antar gelombangnya dapat dijadikan sebagai acuan apakah jantung tersebut normal maupun abnormal. Walaupun hasil pengukuran EKG detak jantung normal tidak seperti standar gambar diatas, tetapi grafiknya memiliki pola yang sama berulang, seperti :

- Gelombang T lebih tinggi dari gelombang P

- $\quad$ Setiap titik Q, R, S pada gelombang QRS dapat terlihat dengan jelas

- Interval gelombang QRS singkat dan sama dalam suatu grafik EKG

- Interval detak jantung bergantung pada usia individu

Seiring bertambahnya usia, pola keteraturan detak jantung dapat berubah. Perubahan keteraturan detak jantung juga bisa menandakan adanya suatu kondisi medis pada jantung atau kondisi medis lain yang perlu segera ditangani. Yang mana pada Gambar 2. adalah contoh jika perubahan pola keteraturan detak jantung yang berpotensi adanya kelainan kesehatan dari jantung itu sendiri.

\section{Hamming Window}

Hamming Window adalah salah satu metode dalam mendesain filter FIR menggunakan grafik persamaan cosinus yang titik ujungnya tidak di nol sehingga masih ada diskontinuitas. Hamming Window meminimalisasi side lobe terdekat yang dapat menambah tingkat derau pada sinyal [8].

Hamming Window dapat didefinisikan sebagai:

$\omega(n)=0.54-0.64 \cos \left(\frac{2 \pi n}{M-1}\right), 0=<\mathrm{n}=<\mathrm{M}-1$

$\mathrm{M}=$ jumlah poin pada output window-nya

\section{E. Wavelet Symlet}

Wavelet adalah osilasi yang berbentuk gelombang dengan aplitudio yang dimulai dari 0 , bertambah, dan berkurang sampai kembali ke 0 . Dengan menggunakan konvolusi, wavelet dapat dikombinasikan dengan sinyal mentah yang terdistorsi oleh derau atau noise untuk mengekstrak informasi yang dibawa oleh sinyal tersebut dengan cara mengurangi atau menghilangkan bising tersebut. Transformasi wavelet adalah pengertian matematis untuk menganalisis sinyal saat frekuensi sinyal berubah terhadap waktu. Analisis wavelet menghasilkan data sinyal yang lebih presisi dibanding analisis sinyal lain [9].

Symlets adalah wavelet yang hampir simetris, ortogonal, dan biortogonal yang diperkenalkan oleh Daubechies sebagai modifikasi dari wavelet Daubechies sebelumnya. Saat diaplikasikan pada sinyal, performa symlet dalam denoisasi lebih baik dibanding Wavelet Daubechies yang sebelumnya [10].

\section{Metodologi Penelitian}

Tahapan penelitian ini meliputi pencarian data, pra pemrosesan, pengolahan sinyal dengan metode denoise Wavelet Symlet, dan perbandingan kualitatif pola sinyal kardiografi hasil pengolahan sinyal manusia normal dengan pengidap penyakit myocardial infarction.

\section{A. Pencarian Data}

Data yang digunakan dalam penelitian ini diperoleh dari archive.physionet.org. Dalam pemilihan data digunakan 4 data manusia sehat yang meliputi:

Tabel 1. Data manusia sehat [11]

\begin{tabular}{|l|l|l|}
\hline Manusia Sehat & Usia & Jenis Kelamin \\
\hline 1 & 25 & Laki-laki \\
\hline 2 & 23 & Perempuan \\
\hline 3 & 21 & Perempuan \\
\hline 4 & 21 & Laki-laki \\
\hline
\end{tabular}

Peneliti juga memilih 4 data pasien pengidap myocardial infarction yang meliputi:

Tabel 2. Data pasien pengidap myocardial infarction [11]

\begin{tabular}{|l|l|l|}
\hline Pasien & Usia & Jenis Kelamin \\
\hline 1 & 81 & Perempuan \\
\hline 2 & 70 & Laki-laki \\
\hline 3 & 49 & Laki-laki \\
\hline 4 & 55 & Perempuan \\
\hline
\end{tabular}


Dari setiap manusia sehat dan pasien diambil satu kali pengukuran sinyal EKG selama 10 detik.

\section{B. Pra Pemrosesan}

Pra pemrosesan terdiri dari 2 tahapan, yaitu tahap pemilihan metode pengolahan sinyal kardiografi dan tahap pengecekan reliabilitas perangkat lunak MATLAB dalam mengolah sinyal kardiografi.

\section{Pemilihan metode pengolahan sinyal kardiografi}

Dalam tahap ini, peneliti mencoba dua metode dalam memproses sinyal kardiografi manusia sehat 1 , meliputi pengolahan sinyal EKG menggunakan FIR filter Hamming Windows dan denoise Wavelet Symlet. Peneliti memilih metode FIR filter Hamming Window sebagai pembandingnya karena metode ini sangat umum digunakan dalam pengolahan sinyal digital dan relatif mudah untuk diaplikasikan. Peneliti memilih metode denoise Wavelet Symlet karena saat diaplikasikan pada sinyal, performa symlet dalam denoisasi lebih baik dibanding Wavelet Daubechies yang sebelumnya [10].

Kemudian dilakukan pengamatan kualitatif dari hasil dua pola sinyal kardiografi. Pengamatan menunjukan metode denoise Wavelet Symlet lebih efektif digunakan dalam mengolah sinyal EKG.

\section{Pengecekan reliabilitas perangkat lunak MATLAB}

Dalam tahap ini, peneliti mencoba melakukan korelasi silang antara pola sinyal kardiografi manusia sehat 1 yang telah difilter dari database physionet.org dengan pola sinyal kardiografi manusia sehat 1 yang telah kami filter melalui denoise Wavelet Symlet menggunakan perangkat lunak MATLAB.

\section{Pengolahan Sinyal dengan Metode denoise Wavelet Symlet}

Seluruh data sinyal EKG dari pasien dipotong terlebih dahulu sebelum dilakukan pengolahan sinyal. Pemotongan ini dilakukan berdasarkan prinsip FIR filter Rectangle Windows tanpa mengubah bentuk asli dari sinyal tersebut. Pemotongan dilakukan untuk mengambil data setiap subjek dari milidetik pertama hingga milidetik ke 1500 atau setara dengan $15 \%$ dari data keseluruhan yang diperoleh dari setiap subjek.

Pengolahan sinyal secara keseluruhan dilakukan dengan metode denoise Wavelet Symlet menggunakan perangkat lunak MATLAB. Pengolahan ini dilakukan satu persatu dari manusia sehat 1 hingga manusia sehat 4 dan dilanjutkan dengan pasien 1 hingga pasien 4 .

D. Perbandingan kualitatif pola sinyal kardiografi hasil pengolahan sinyal manusia normal dengan pengidap penyakit myocardial infarction

Dalam tahap ini, peneliti mencoba untuk membandingkan pola sinyal hasil denoise Wavelet
Symlet dari semua data yang ada. Pengamatan utama terdapat pada persamaan pola sinyal manusia sehat 1 , manusia sehat 2 , manusia sehat 3 , dan manusia sehat 4. Dilanjutkan dengan pengamatan pada persamaan pola pasien 1, pasien 2, pasien 3, dan pasien 4 . Kemudian, dilakukan pengamatan terhadap perbedaan pola sinyal antara manusia sehat dengan pasien pengidap myocardial infarction.

\section{HASIL DAN ANALISIS}

Dalam penelitian ini diperoleh tiga hasil utama yang meliputi hasil pemilihan metode untuk pengolahan data, hasil pengujian reabilitas MATLAB, dan hasil perbandingan pola sinyal kardiografi pengidap myocardial infarction dengan jantung normal.

\section{A. Pemilihan Metode Pengolahan Sinyal EKG} Menggunakan denoise Wavelet Symlet

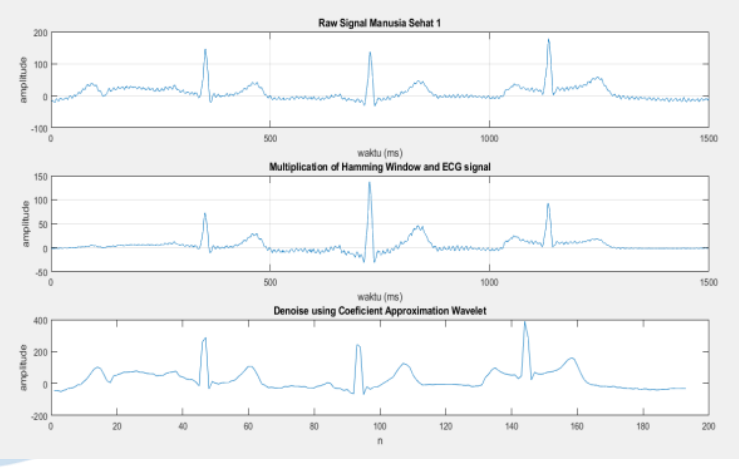

Gambar 3. Perbandingan pengolahan sinyal menggunakan FIR filter Hamming Window dan denoise Wavelet Symlet pada sinyal EKG

Melalui Gambar 3, terlihat bahwa metode FIR filter Hamming Window maupun metode denoise Wavelet Symlet sama-sama mampu mengurangi derau yang ada pada sinyal kardiografi. Namun, terdapat beberapa perbedaan yang membuat metode denoise Wavelet Symlet dipilih dalam mengolah data pada penelitian ini.

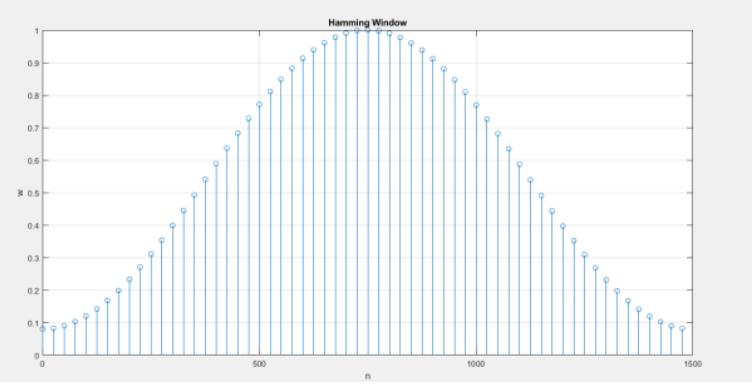

Gambar 4. Bentuk FIR filter Hamming Wind 
Pertama, dapat terlihat bahwa sebenarnya Hamming Window secara keseluruhan memfilter sinyal EKG dengan menghilangkan beberapa informasi sinyal pada bagian awal dan akhir serta meng-highlight sinyal pada bagian tengah. Hal ini tidak sesuai dengan kebutuhan olah sinyal EKG karena akan membuat dokter ataupun petugas medis mengalami salah pembacaan informasi yang disampaikan oleh sinyal. Lebih lagi, pola berulang yang dimiliki oleh sinyal EKG menjadi tidak terdeteksi sehingga ketika menggunakan FIR filter Hamming Window dalam mengolah sinyal EKG akan menimbulkan kesalahan penanganan terhadap pasien.

Kedua, melalui grafik hasil denoise wavelet symlet, peneliti memperoleh pola sinyal kardiografi yang berulang dengan mudah sesuai dengan teori yang ada. Hal ini, diakibatkan oleh halusnya grafik hasil olahan data denoise Wavelet Symlet sehingga memudahkan pembacaan informasi yang dikandung oleh sinyal EKG.

Oleh sebab itu, dalam mengolah sinyal EKG metode denoise Wavelet Symlet adalah metode yang paling tepat untuk digunakan.

\section{B. Pengujian Reliabilitas MATLAB}

Pengujian ini dilakukan dengan cara membandingkan grafik EKG hasil filter dari database physionet.org dengan hasil olah sinyal menggunakan metode denoise wavelet symlet yang dilakukan oleh peneliti, kemudian dilakukan pengecekan korelasi silang antara kedua grafik yang diperoleh.

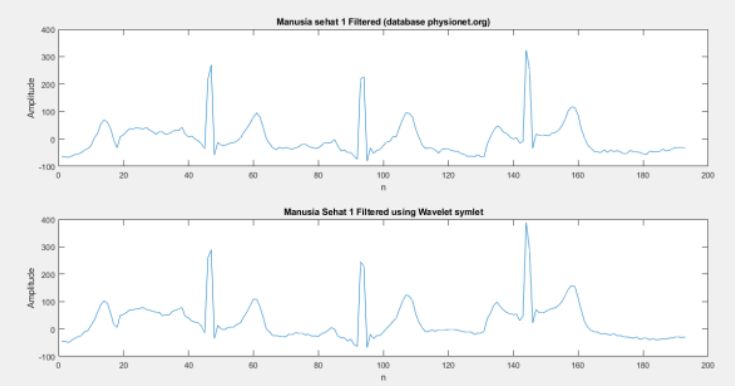

Gambar 5. Perbandingan sinyal EKG hasil filter database dengan hasil olah sinyal Wavelet Symlet

Ketika peneliti mengamati Gambar 5, dapat ditemukan perbedaan yang mencolok, yaitu hasil olah sinyal Wavelet Symlet menghasilkan pola yang lebih halus dibandingkan dengan hasil filter database. Hal ini diduga akibat aproksimasi nilai yang dilakukan menggunakan wavelet membuat data dengan sedikit kestabilan dianggap merupakan bagian dari derau sehingga dihilangkan. Namun, jika dilihat secara keseluruhan, kedua hasil olah data tersebut tetap memiliki pola yang sama dan serupa. Hal ini dibuktikan melalui hasil korelasi silang antara kedua grafik sebagai berikut.

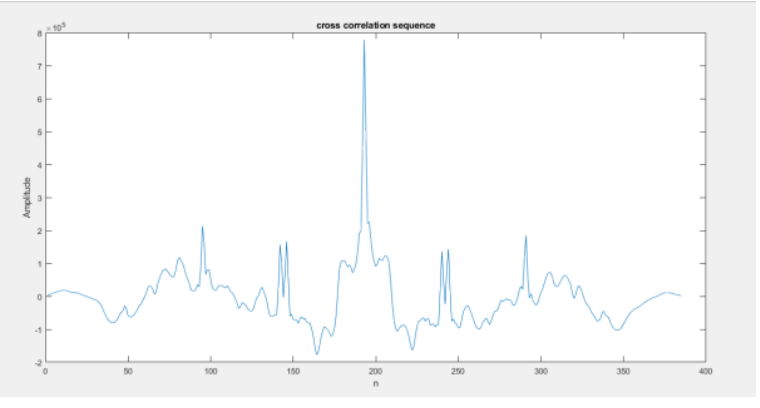

Gambar 6. Korelasi silang sinyal EKG hasil filter database dengan hasil olah sinyal Wavelet Symlet

Melalui Gambar 6, terlihat bahwa hasil korelasi silang memiliki sisi kanan dan sisi kiri yang serupa sekalipun tidak seluruhnya semetris. Melalui grafik tersebut, peneliti berkesimpulan bahwa setidaknya, hasil korelasi silang tersebut menyatakan bahwa sinyal EKG hasil filter database sangat berkorelasi dengan hasil olah sinyal Wavelet Symlet. Hasil analisis ini menunjukkan bahwa tingkat reliabilitas MATLAB dalam mengolah sinyal EKG sudah cukup handal.

C. Perbandingan Kualitatif Pola Sinyal Kardiografi Hasil Pengolahan Sinyal Manusia Normal dengan Pengidap Penyakit Myocardial Infarction

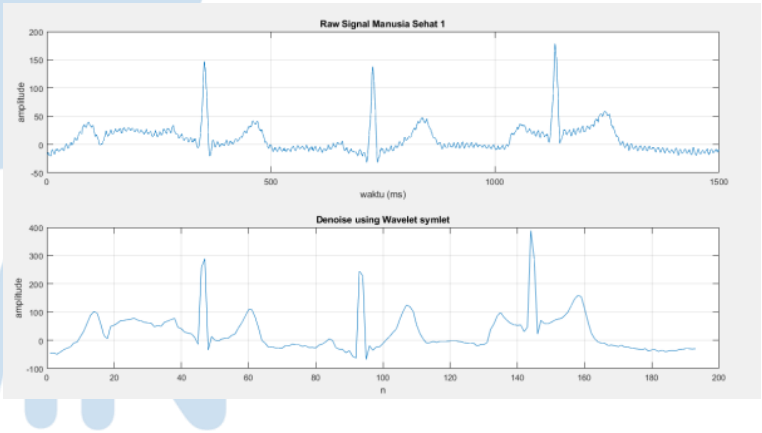

Gambar 7. Sinyal EKG manusia sehat 1

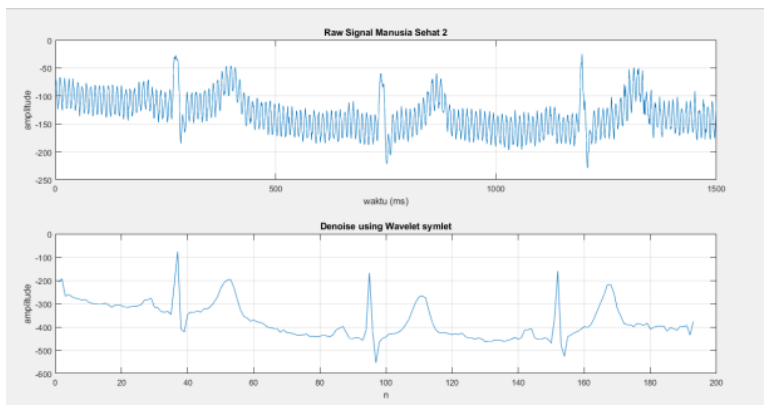

Gambar 8. Sinyal EKG manusia sehat 2 


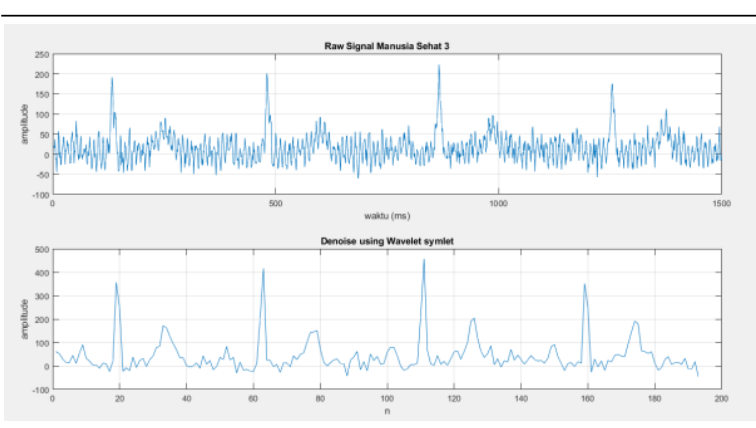

Gambar 9. Sinyal EKG manusia sehat 3

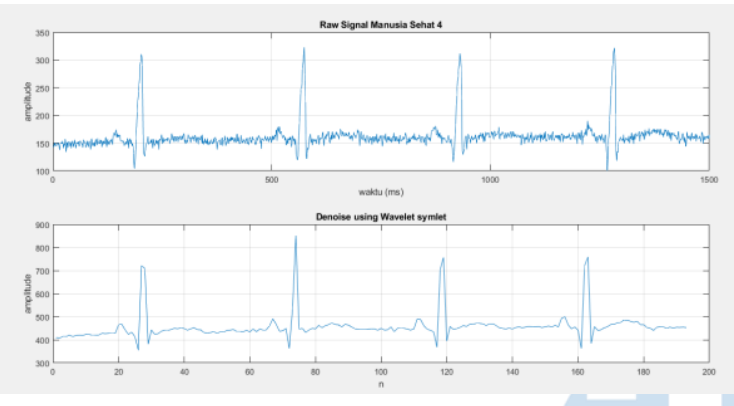

Gambar 10. Sinyal EKG manusia sehat 4

Dari keempat grafik manusia sehat diatas ditemukan beberapa kesamaan sebagai berikut: pertama, selalu ditemukan pola kardiografi yang tepat meliputi bagian $\mathrm{P}, \mathrm{Q}$, R-peak, $\mathrm{S}$, dan T sesuai dengan dasar teori.

Kedua, nilai R-peak berkisar antara 150-400 satuan pada amplitudo. Nilai ini menunjukan daya yang dikeluarkan jantung untuk memompa darah ke seluruh tubuh.

Ketiga, dalam jangka waktu 1500 milidetik, terbentuk 3-4 kali pola yang sama/serupa. Secara mudah dapat kita lihat pada pembentukan R-peak artinya jantung manusia normal akan berdetak sebanyak 3-4 kali dalam 1,5 detik.

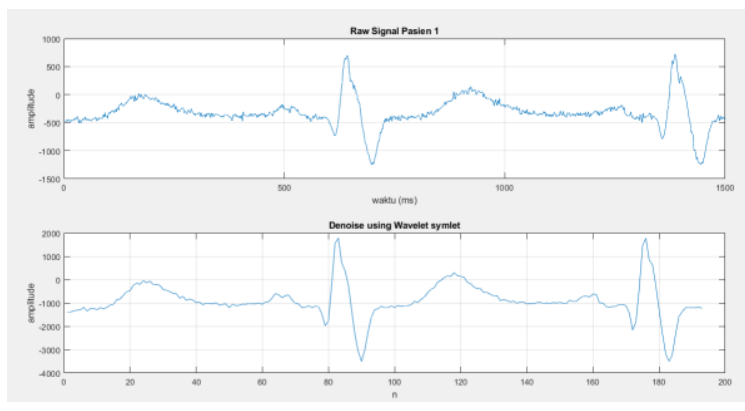

Gambar 11. Sinyal EKG pasien 1

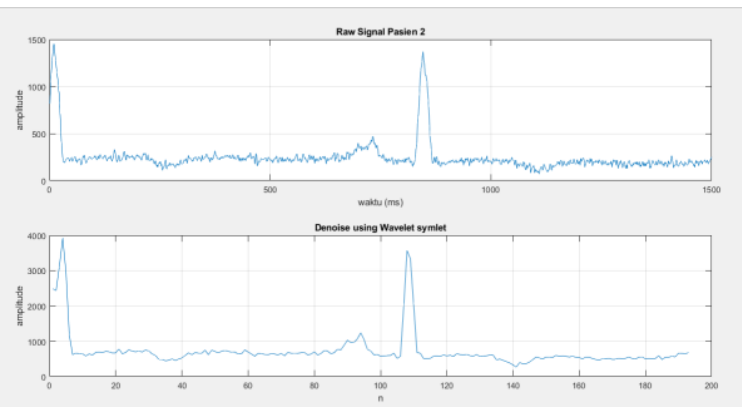

Gambar 12. Sinyal EKG pasien 2

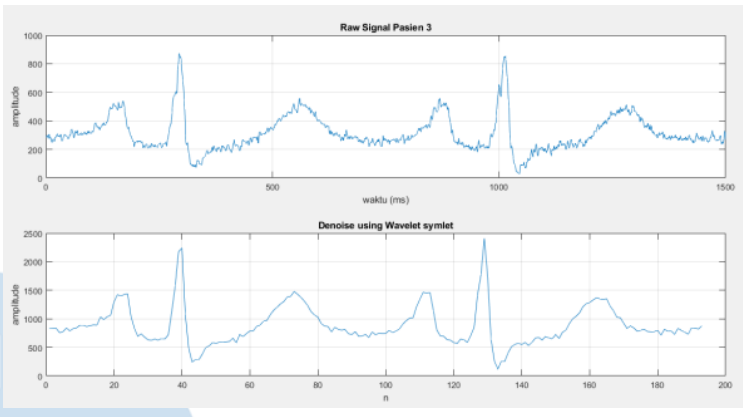

Gambar 13. Sinyal EKG pasien 3

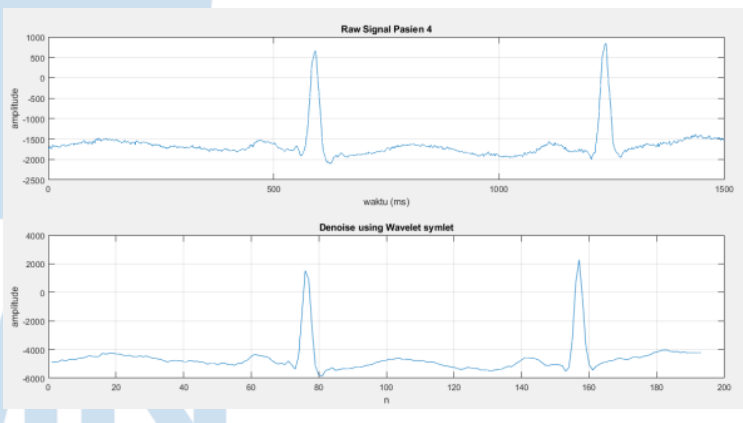

Gambar 14. Sinyal EKG pasien 4

Selanjutnya, dari keempat grafik pasien pengidap myocardial infarction diatas ditemukan beberapa kesamaan sebagai berikut: pertama, biasanya ditemukan masalah pada pola kardiografi bagian $\mathrm{P}$ dan T. Pada pasien 2 bagian T tidak terdeteksi atau bahkan bernilai negative. Pada pasien 3 bagian $\mathrm{P}$ memiliki amplitudo yang terlalu tinggi hingga setara dengan bagian $\mathrm{T}$, hasil ini menunjukan adanya ketidaksesuaian pola dengan dasar teori. Pada pasien 4 bagian $\mathrm{T}$ memiliki amplitudo yang terlalu rendah bahkan lebih rendah dari pada bagian $\mathrm{P}$ yang juga menunjukan ketidaksesuaian dengan dasar teori. Hanya pasien 1 yang memiliki pola kardiografi yang tepat meliputi bagian $\mathrm{P}$ dan $\mathrm{T}$ sesuai dengan dasar teori. Artinya menurut penelitian ini, sebesar $75 \%$ dari pengidap myocardial infarction akan memiliki bagian $\mathrm{P}$ dan $\mathrm{T}$ yang tidak sesuai dengan pola jantung normal. 
Kedua, nilai R-peak berkisar antara 3000-6000 satuan pada amplitudo. Nilai ini menunjukan daya yang dikeluarkan jantung untuk memompa darah ke seluruh tubuh. Artinya penderita myocardial infarction membutuhkan daya pompa jantung yang sedemikian besar untuk mampu mengalirkan darah ke seluruh tubuh. Hal ini diduga akibat adanya penumpukan plak pada pembulu darah akibat kadar kolestrol tinggi yang mengakibatkan adanya hambatan saat mengalirkan darah ke seluruh organ tubuh.

Ketiga, dalam jangka waktu 1500 milidetik, terbentuk rata-rata 2 kali R-peak. Artinya, jantung pengidap myocardial infarction akan berdetak sebanyak 2 kali dalam 1,5 detik.

Keempat, adanya jarak yang cukup regang antara bagian Q-S. Hal ini terlihat dengan jelas jika kita membandingkan pola jantung pasien pengidap myocardial infarction dengan pola jantung normal.

Kelima, pasien myocardial infarction memiliki ketidak-konsistenan pola antara satu pasien dengan pasien yang lainnya, artinya efek dari myocardial infarction yang ditimbulkan pada pola jantung adalah dapat membuat pola jantung menjadi acak tergantung letak sumbatan pembulu darah yang dialami oleh pasien tersebut.

Terakhir, peneliti melakukan perbandingan untuk membedakan pola jantung normal dengan pola jantung pasien pengidap myocardial infarction berdasarkan persamaan yang telah dianalisis sebelumnya, dan diperoleh hasil sebagai berikut :

- Pada sebagian besar pasien pengidap myocardial infarction akan ditemukan kesalahan pola kardiografi pada bagian $\mathrm{P}$ dan $\mathrm{T}$.

- Nilai R-peak (dihitung dari baseline) pasien pengidap myocardial infarction lebih besar kurang lebih 20X dari nilai R-peak jantung normal.

- Detak jantung pasien pengidap myocardial infarction lebih lambat dibandingkan detak jantung normal.

- Bagian Q-S pada pola kardiografi pengidap myocardial infarction lebih regang dibandingkan dengan pola jantung normal.

- Per satu detakan jantung pengidap myocardial infarction memiliki durasi yang lebih lama dibanding per satu detakan jantung normal.

- Pola kardiografi secara keseluruhan yang dimiliki oleh pasien pengidap myocardial infarction akan berbeda antara satu dengan yang lainnya tergantung pada letak kerusakan bagian jantung yang dialami oleh masing-masing pasien.

\section{SimpUlaN}

Metode denoise wavelet symlet lebih efektif dalam menghilangkan derau dibanding filter FIR dengan Hamming Window dalam mengolah sinyal EKG. Software MATLAB juga memiliki reliabilitas yang tinggi dalam mencitrakan hasil filter dari sinyal EKG.

Kemudian dalam perbandingan kualitatif diperoleh bahwa manusia dengan gangguan jantung myocardial infarction memiliki detak jantung yang lebih lambat yaitu 2 detakan dibandingkan dengan manusia normal yang memiliki 3-4 detakan dalam 1,5 detik. Jantung manusia dengan gangguan myocardial infarction juga memerlukan kerja yang jauh lebih besar, sekitar 20 kali lebih besar dibandingkan kerja jantung manusia normal. Pola jantung yang tidak beraturan bagi pengidap myocardial infarction juga menjadi salah satu penyebab sulitnya mendeteksi penyakit ini melalui sinyal EKG. Namun, ciri-ciri yang ditemukan dalam penelitian ini meliputi kesalahan pola pada bagian P dan T, serta jarak Q-S yang regang dalam sinyal EKG dapat menjadi salah satu titik acuan diagnosa seseorang mengalami myocardial infarction.

\section{DISKUSI DAN SARAN}

Penelitian ini memiliki masih beberapa kekurangan diantaranya adalah peneliti tidak melakukan validasi data mentah. Peneliti hanya mempercayai bahwa data yang diperoleh dari physionet.org adalah data benar yang merupakan sinyal EKG baik dari manusia sehat maupun pasien penderita myocardial infarction. Selanjutnya, analisis yang dilakukan oleh penelitian ini merupakan analisis kualitatif yang hanya diperoleh melalui pengamatan grafik hasil pengolahan sinyal. Kemudian pengolahan sinyal juga hanya dilakukan secara sederhana yaitu melalui penghilangan derau. Masih banyak hal yang dapat dilakukan untuk membuat sinyal EKG ini lebih mudah terbaca dan memperoleh informasi yang akurat.

Peneliti juga berharap penelitian ini dapat dikembangkan lebih jauh. Namun, keterbatasan pengetahuan tentang dunia kedokteran dan medis menjadi salah satu rintangan utama terhambatnya analisis pada penelitian ini. Pengamatan grafik secara kuantitatif berdasarkan teori yang benar dan akurat secara medis juga dapat meningkatkan kualitas dari penelitian ini.

\section{UCAPAN TERIMA KASIH}

Ucapan terima kasih kepada segala pihak yang mendukung terselesaikannya penelitian ini yang tidak dapat disebutkan satu per satu.

\section{DAFTAR PUSTAKA}

[1] kumparanNEWS, "Penyakit Jantung di RI: Ancaman Kematian Nomor 1, Paling Banyak Serang PNS," kumparan, 
18-Feb-2020. [Online]. Available: https://kumparan.com/kumparannews/penyakit-jantung-di-riancaman-kematian-nomor-1-paling-banyak-serang-pns1srfmn3qGvA/full. [Accessed: 03-Jun-2020].

[2] E. L. Utari and A. Q. Munir, "Simposium Nasional RAPI XII," Pengenalan Pola Sinyal Kardiografi Menggunakan Alih Ragam Gelombang Singkat, pp. E151-E158, 2014.

[3] Alodokter, "Serangan Jantung," Alodokter, 04-Dec-2019. [Online]. Available: https://www.alodokter.com/seranganjantung. [Accessed: 08-Jun-2020].

[4] K. A. Setiaputri, "Elektrokardiografi (EKG), Tes Deteksi Masalah Irama Denyut Jantung," helloSEHAT, 26-Mar-2020. [Online]. Available: https://hellosehat.com/hidup-sehat/faktaunik/ekg-adalah-elektrokardiografi/. [Accessed: 26-Mar2020].

[5] J. R. Hampton, The ECG Made Easy, 8th ed. London, England: Elsevier Health Sciences UK, 2013.

[6] "Riview Medical Surgical Nursing Test Faculty of Nursing, Klabat University." [Online]. Available: https://docplayer.info/110743082-Riview-medical-surgicalnursing-test-faculty-of-nursing-klabat-university.html.

[Accessed: 08-Jun-2020].
[7] "Apakah Denyut Jantung Anda Tidak Normal? Semua tentang aritmia," Mount Elizabeth Hospital. [Online]. Available:

https://www.mountelizabeth.com.sg/id/healthplus/article/arrh ythmia-guide. [Accessed: 08-Jun-2020].

[8] A. Gavel, H. L. Sahu, G. Sharma, and P. K. Rahi, "Design of High Pass Fir Filter Using Rectangular, Hanning and Kaiser Window Techniques," International Journal for Research in Applied Science and Engineering Technology, vol. III, no. VIII, pp. 251-256, Aug. 2016.

[9] "Wavelet Transforms in MATLAB," MATLAB \&amp Simulink. [Online]. Available: https://www.mathworks.com/discovery/wavelettransforms.html. [Accessed: 02-May-2020].

[10] M. S. Chavan, N. Mastorakis, M. N. Chavan, and M. S Gaikwad, "NEHIPISICS," Implementation of SYMLET Wavelets to Removal of Gaussian Additive Noise from Speech Signal, pp. 37-41, 2011.

[11] "archive.physionet.org," PsysioBankATM. [Online]. Available: https://archive.physionet.org/cgi-bin/atm/ATM [Accessed: 2020].

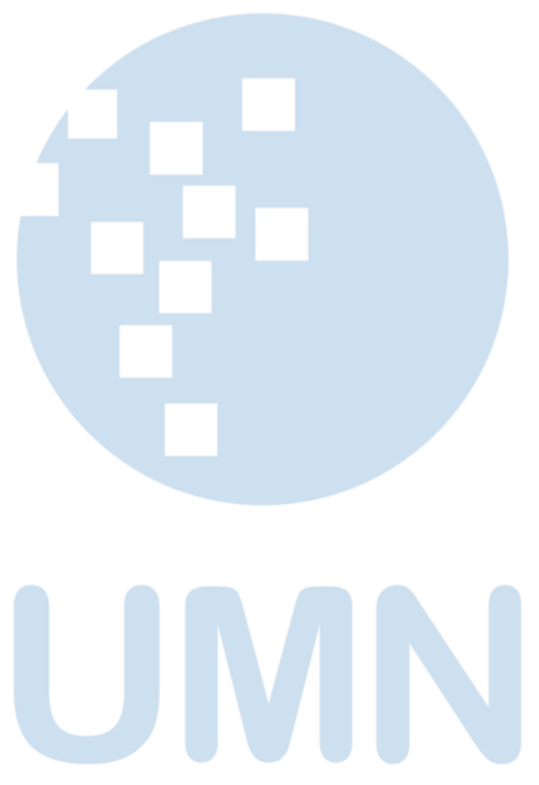

